\title{
Non-Keratinizing Primary Intraosseous Squamous Cell Carcinoma -Solid Type
}

National Cancer Institute

\section{Source}

National Cancer Institute. Non-Keratinizing Primary Intraosseous Squamous Cell

Carcinoma -Solid Type. NCI Thesaurus. Code C7499.

A squamous cell carcinoma that arises centrally from the jaw. It is characterized by a solid pattern, lack of prominent keratinization, infiltration of the marrow spaces, and osseous resorption. 